brown, po tscutellum dark brown. Abdomen dark reddish-brown; genitalia with a reddish cast. Wings hyaline, costa reddish brown. Halteres reddish brown, yellowish basally. Coxx reddish brown, the legs mostly pale straw, the tarsi slightly darker; claws moderately stout, slightly curved, simple, the pulvilli longer than the clans. Genitalia; basal clasp segment moderately long, stout; terminal clasp segment short, tapering and curving apically; dorsal plate short, broad, broadly and triangularly emarginate, the lobes somewhat divergent and broadly rounded; ventral plate long, broad, deeply, roundly and triangularly emarginate, the lobes tapering to a narrowly rounded, setose apex.

Female--Length, $4 \mathrm{~mm}$. Antenns probably extending to the third abdominal segment, sparsely haired, reddish-brown; 14 segments, the fourth with a stem onefourth the length of the subcylindric basal enlargement, which latter has a length two and one-half times its diameter and is slightly expanded apically. Palpi; the first segment roundly triangular, the second with a length more than three times its diameter, the third a little shortcr than the second and the fourth one-half longer than the third. Abdomen reddish-brown. Ovipositor short, with a length less than one-third the abdomen, the terminal lobes narrowly oval and thickly setose. Type Cecid. a2622.

Described from balsam preparations, colors approximate.

\title{
THE RHODODENDRON LACE-BUG, LEPTOBYRSA EXPLANATA HEIDEMANN
}

\author{
(Tingitido, Hemiptera)
}

By C. R. Crosby and C. H. Hadley, JR., Ithaca, N. Y.1

As early as 1906, this tingid had been noted as being abundant and causing considerable injury to rhododendrons in several localities in New York. In 1908, Heidemann described it as a new species, adopting the manuscript name of Professor Uhler, Leptobyrsa explanata. Since then its presence has been observed every year, often being abundant enough to cause serious injury.

\section{Distribution}

This insect is more or less widely distributed from North Carolina to Massachusetts, and as far west as Ohio. It has been found in the following states: North Carolina, Maryland, District of Columbia, Pennsylyania, West Virginia, Ohio, New Jersey, New York, Connecticut and Massachusetts, and is probably present in others also. In New York it is found in a number of places.

\section{Hosts}

This insect has been recorded as abundant on mountain laurel, Kalmia latifolia, and rhododendron or great laurel, Rhododendron

\footnotetext{
${ }^{1}$ Contribution from the Department of Entomology of Cornell University.
} 
maximum. We have observed it breeding abundantly on rhododendron in the Rochester parks and in private grounds at Ithaca.

We have also received specimens from nurseries at Lynbrook, Long Island, on rhododendron, and from Franklin Park, Boston, Mass., on mountain laurel. In April 1908, eggs were found in abundance on wild rhododendron at Port Jervis, N. Y.

\section{INJURY}

The leaves are disfigured on the underside along the midrib by the brownish scabs which cover the eggs, as described below. The greatest injury is caused by the nymphs and adults feeding on the under surface of the leaf. They suck the sap, causing a lighter colored spattered appearance on the upper surface, of ten with consequent drying and shriveling of the leaf. The sale of rhododendrons is also sometimes hindered by the unsightly appearance of the undersides of the leaves, due to the excrement left there by the insects.

\section{Life Hustory}

Egg. $-5.54 \mathrm{~mm}$. long by $.24 \mathrm{~mm}$. wide. It is flask-shaped with the neck bent to one side. The anterior end is obliquely truncate and provided with an oval lid. This lid has a submarginal ridge which encloses an oval impressed area. The egg is smooth, without sculpture, and is white, except near the anterior end where it is somewhat brownish. The eggs are usually inserted in a more or less irregular row along the midrib on the underside of the leaf, but occasionally in the leaf a short distance away from the midrib, on either side. The leaf tissue surrounding the egg becomes hardened and corky, but this hardening is entirely internal and makes no noticeable change on the surface of the leaf. In removing the egg with a needle, this gall-like growth is easily separated from the normal tissue. The lid is nearly on a level with the leaf surface and is protected by a drop of a brownish substance deposited by the parent insect, and has the appearance of a small scab. When the eggs are abundant, these scabs are quite noticeable along the underside of the leaf. Often these scabs drop off several days before the eggs hatch, exposing the egg cap. The eggs are laid in the newer leaves, and the winter is passed in this stage.

Nymph.-At Ithaca, the eggs hatch in late May or carly June, depending on the weather. They have been observed hatching outdoors on June 6, and had apparently all hatched by June 17. In 1908, first, second and third stage nymphs were observed out of doors on June 2.

\section{Explanation of Plate 22}

1. Injured and uninjured leaves, showing eggs and disfiguring on underside of leaf.

2. Eggs in position in leaf tissue.

3. Location of eggs along midrib. 


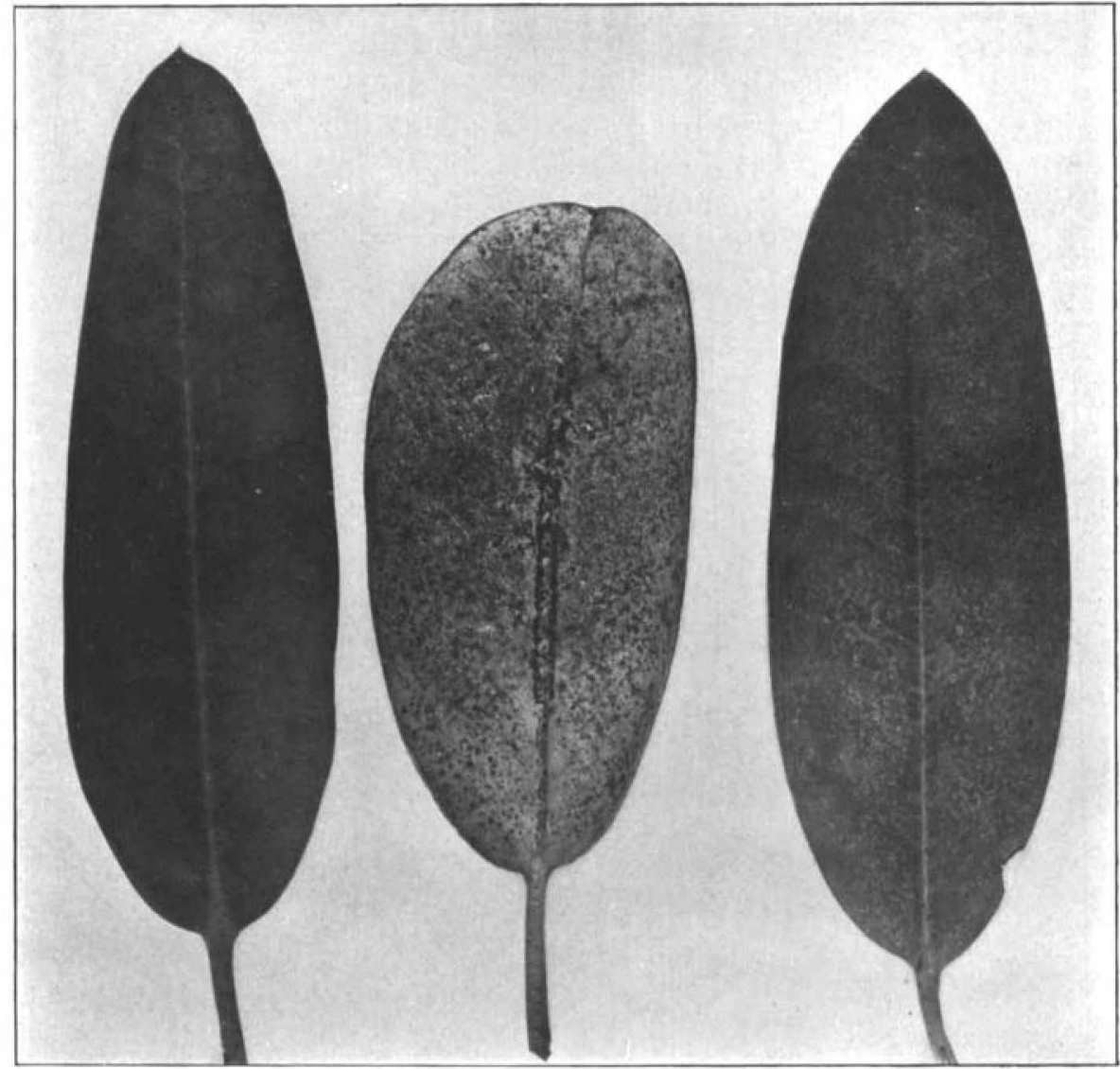

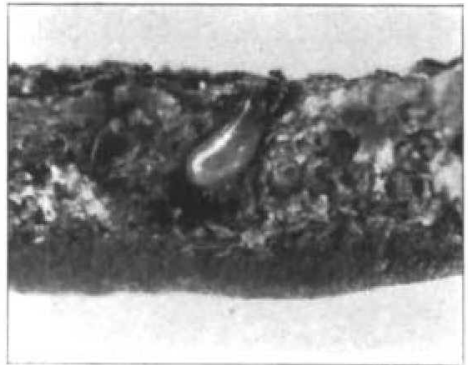

2

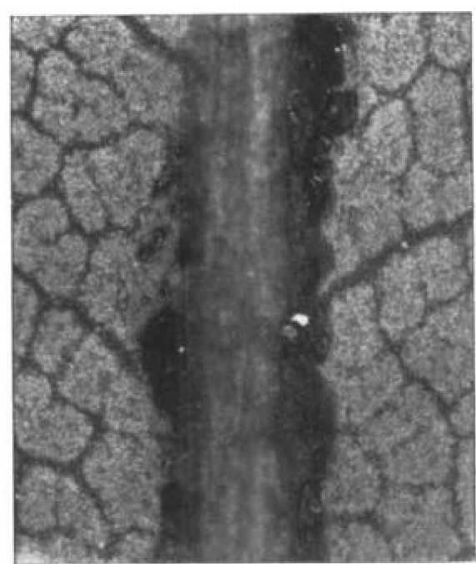

3

Rhodorlendron Lace Bug 
Mr. Dunbar states that he observed the young nymphs on May 25, 1906, on rhododendrons in Hyland Park, Rochester, N. Y. In hatching, the end of the egg enlarges slightly, becoming almost transparent. Then the nymph gradually emerges, the red eye-spots showing very conspicuously. The body sways back and forth slowly, during emergence, with slight spasmodic movements. When all the body has emerged except the last two or three segments, the spines along the sides of the body and the legs unfold and stiffen out. Then the leaf surface is grasped by the claws of the legs, and the insect is able with this help to withdraw the body entirely. Often the egg shell is drawn partly out of its pocket by this last effort. The newly emerged insect rests for several minutes after its exertions, then it slowly walks around, secking a suitable feeding place. When first emerged the nymph is colorless, almost transparent, except for the bright red eyes. Soon after feeding commences, it begins to darken up.

The nymphs feed in groups, remaining in a place a short time, then moving to a new location. The characteristic feeding attitude is with the body inclined upward towards the head, the antennæ straight outward slightly diverging. At intervals the body sways slightly from side to side. After feeding a short time, the proboscis is withdrawn, and the slender inner sucking tube is carefully cleaned with the forefeet, in much the same fashion as the ordinary house fly.

\section{Description of Nrmphal Stages}

First stage.-Length, $0.75 \mathrm{~mm}$. At first nearly colorless but gradually becoming darker at base of legs and at base and tip of antennx and beak, abdomen appearing greenish from the ingesta. Head rounded in front, narrowed behind the eyes, armed with five strong tubercles, two above the base of beak, one just behind these bearing two hairs and two near the posterior margin. Eyes consisting of five distinct ommatidia, bright red, prominent. Thorax a little narrower than abdomen. On each thoracic segment and on each abdominal except the first there is on each side near the lateral margin a simple hair borne on a minute tubercle. On the mesothorax there is a median pair of small hairs. On abdominal segments $2,5,6$ and 8 there is a large double median tubercle bearing at its tip two short hairs. All these hairs sccrete a sticky substance which hangs as a clear drop at the end. Antennie threefourths the length of the body, four-jointed, the two basal segments short, third the longest, fourth slightly more than half as long as the third. Beak in newly hatched specimens nearly as long as body, after feeding reaching only to second abdominal segment.

Second stage.-Length $0.9 \mathrm{~mm}$. In general much like first stage except that lateral margin of abdomen is slightly more explanate and the dusky parts have become darker. Abdomen and lateral part of thorax dusky. The tubercles on the head are much longer, quite slender and of a dusky color. The lateral tubercles on the proand mesothorax and on abdominal segments 4-9 are much larger, those on the metathorax and on abdominal segments 2 and 3 are small. There seems to be no tubercle on the first abdominal segment. The dorsal tubercle is much larger than in preceding stage and bears four or five hairs. The dorsal abdominal tubercles are much larger and bear a cluster of hairs, the one on the second segment being smaller than the 


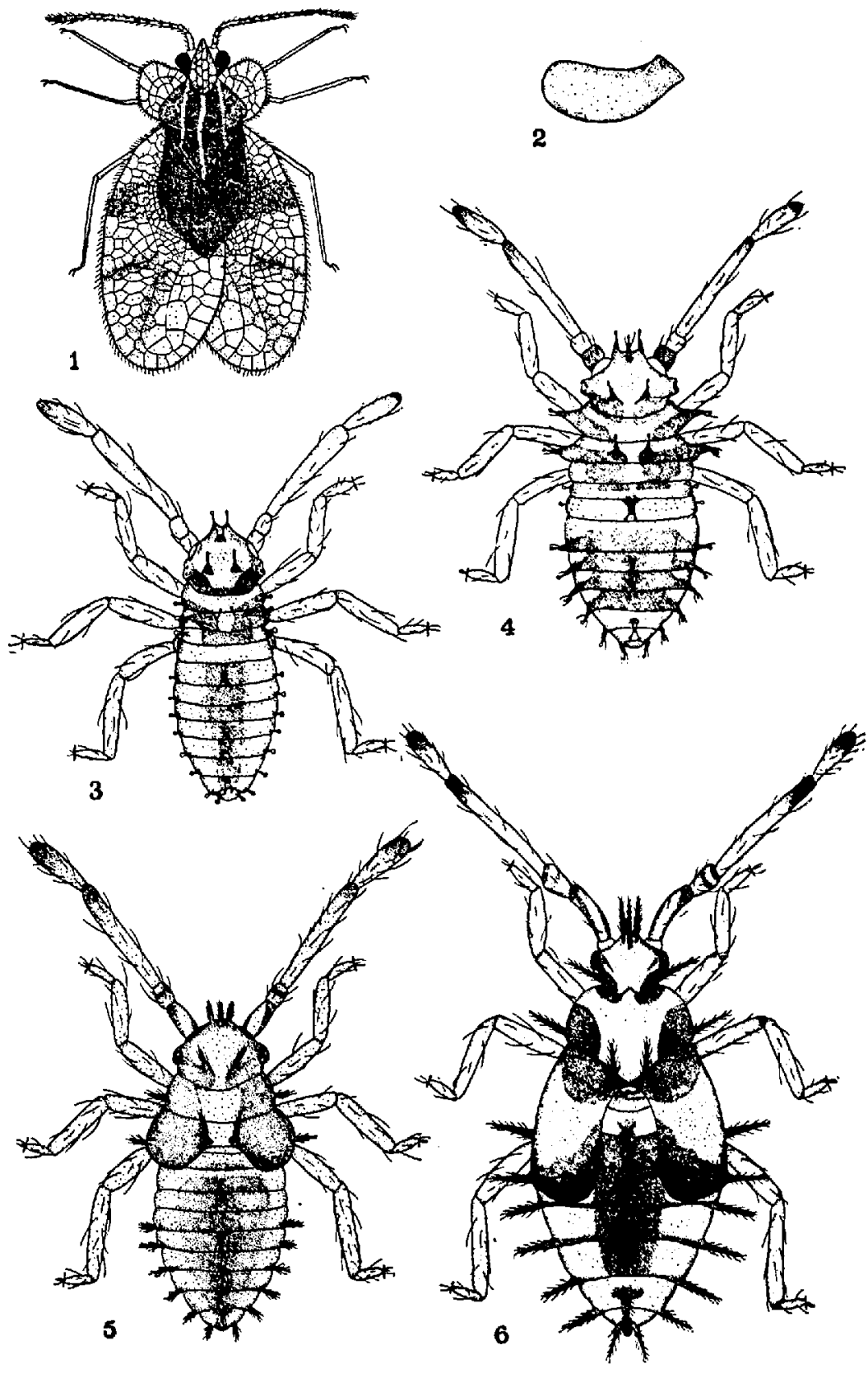

Rhododendron Lace Bug 
others. Towards the last of this stage two small ommatidia begin to show on the anterior side of the group.

Thirl stage.-Length including tubercles on head $1.4 \mathrm{~mm}$. Outer side of first, tip of second, third and fourth joints of antenna, all the large tubercles on body, wingpads and dorsum of abdomen dusky with a greenish tinge. The outline of the eye is now distinct and the ommatidia numerous, red. The wing-pads are conspicuous and extend to second abdominal segment. The tubercles which had increased in size in the preceding stage have become still larger and bcar more glandular hairs while the smaller areas scem to have become obsolete.

Fourth stage.-Length including tubercles on head, $2.25 \mathrm{~mm}$. All tubercles have become longer, more slender and are dusky. The sides of prothorax are more explanate, the posterior margin is slightly biconcave, while the rounded median portion extends between the mesothoracic tubercles. The wing-pads extend to the fifth abdominal segment; the lateral tubercles of the mesothorax occupy the extreme margin of the wing-pad and are nearer the apex than the base. Color dull yellowish; base and tip of wing-pads, large oval spot on abdomen, spots at base of tubercles and outer side of first, tip of second and third, and distal two-thirds of fourth segment of antennæ dusky with a greenish tinge. Legs dull yellowish, tip of tarsi dusky.

Under insectary conditions, the length of the nymphal stages has been found to be as follows:

First stage, 6 to 7 days;

Second stage, 4 to 6 days;

Third stage, 3 to 6 days;

Fourth stage, 12 to 15 days.

Tnder outdoor conditions, the length of stages is probably a little greater, as adults have been seen mating on July 20, and laying eggs on July 25.

Adult. ${ }^{1-B o d y}$ short, oval in the female, more elongate in the male, shining black; membranous parts of pronotum and integument of elytra pale yellowish, semitranslucent, nervures yellowish. Head rather small, black, with tluree white frontal spines, two approaching each other, the middle one comparatively stouter; besides, there are two other more slender spines extending from behind the eyes towards front. Antenna long, finely pilose, yellowish, the tips infuscated; two basal joints slightly thicker than the following ones, first joint twice the length of second, third little more than three times as long as fourth. Bucculæ yellowish, narrow, angulate and broader behind, the edge upturned a little. Pronotum transverse, feebly convex, coarsely punctured, and shining black; in fresh specimens the sides of the pronotum are covered

\section{Explanation of Plate 23}

Fig. 1. Adult.

Leptobyrsa explanata Heid.

Fig. 2. Egg.

Fig. 3. First stage nymph.

Fig. 4. Second stage nymph.

Fig. 5. Third stage nymph.

Fig. 6. Fourth stage nymph.

${ }^{1}$ Heidemann, O. Proc. Ent. Soc. Wash. X, 105-108. 
with a whitish film that also extends toward the underside at the sternum. Hood not much inflated, cristate and slightly tapering towards front; covering the head, except the eyes, with quite large areoles at the sides near top and a few smaller ones at lower part. The three pronotal carinæ yellowish, the median one strongly declining towards apex of the triangular posterior portion of pronotum, with a row of long, large areoles of which the middle ones are divided by, a few cross nervures and embrowned; outer carinæ very low, only half as long as the median carina, extending from base of hood to sides of pronotal portion posteriorly; the triangular part of pronotum rather short, yellowish and finely reticulated; membranous pronotal margins strongly rounded behind, reflexed, widening moderately at sides, narrowing toward the neck and reaching the lower part of hood close to the eyes, with two or three rows of average-sized areoles. Elytra ovate, iridescent, extending one-half their length beyond abdomen, a little less in the male; discoidal area pyriform and short, angularly raised at the outer nervure, somewhat rounded at apex and broadly scooped out on the upper surface, with three or four rows of quite large areoles at the widest part. Subcostal area subvertical, wider than the discoidal area, having about five rows of irregular small areoles, those of the upper row much larger; costal area broadly expanded, with four or five rows of very large, more or less irregular areoles, diminishing to three and two rows at base. Surface of elytra very peculiarly undulated, with two transverse, sharp impressions, and another at apex formed by the outer nervure of subcostal area; a light transverse fascia on basal half. Median nervure of subcostal area strongly sinuate towards tip of elytra; sutural area at inner part irregularly reticulated with rows of some extremely large areoles. Entire margin of elytra, lateral margins of pronotum, crest of hood, carina, and most of the nervures beset closely with long, very fine hairs. Rostral groove uninterrupted, broad at mesosternum and metasternum, angularly closed in front; rostrum reaching metasternum. Abdomen of female broadly rounded at apex, in the male more elongate, the sides of genital segment sinuated; at tip two strong claspers. Length 3.6 $\mathrm{mm}$.; width of each elytron across widest part, $1.4 \mathrm{~mm}$.

\section{Control}

Our experience has shown that it is not a difficult matter to control these insects. They may be killed by a soap and water spray, at the rate of 1 pound soap to 10 gallons water. The spray should be directed at the under side of the leaves, and applied as soon as the nymphs are observed. It may be necessary sometimes to spray more than once during the season. Any good soap may be used without injury to the leaves. In the case of rhododendron, care should be taken not to spray the plants while the hot sun is shining; otherwise the leaves will be scorched.

\section{References}

1908. Heidemann, O., Proc. Ent. Soc. Wash., X, pp. 105-108.

1909. Sмiтн, J. B., "Insects of N. J.," p. 148.

1910. FeLt, E. P., 25th Rpt. N. Y. State Ent., pp. 72-75.

1911. Britton, W. E., 10th Rpt. Conn. State Ent., pp. 708-9.

1914. Headlee, T. J., Rpt. N. J. State Ent. for 1913 , p. 652. 